\title{
Revisiting Economic Development in Post-war Taiwan: The Dynamic Process of Geographical Industrialization
}

\author{
JINN-YUH HSU* and LU-LIN CHENG† \\ ^Department of Geography, National Taiwan University, Taipei 106, Taiwan. Email: jinnyuh@ccms.ntu.edu.tw \\ †Institute of Sociology, Academia Sinica, Taipei 111, Taiwan.Email: llcheng@sinica.edu.tw
}

(Received September 2001; in revised form January 2002)

Hsu J.-Y. and Cheng L.L. (2002) Revisiting economic development in post-war Taiwan: the dynamic process of geographical industrialization, Reg. Studies 36, 897-908. Taiwan's post-war economic growth has been spectacular and has attracted divergent, even contrasting, explanations from the students of economic development. While neo-classicists interpret Taiwan's Miracle as a model of a free market economy, the statists put government policy as their main emphasis. However, neither the neoliberalists nor the statists take the phenomena of uneven development very seriously. By ignoring the process of geographical industrialization, both discourses are not able to reveal the dynamic rhythm, and more importantly the diversity and possibility, of capitalist development. This paper tackles the issue by unraveling the divergent regional industrial trajectories and the resulting geographical and social embeddedness in post-war Taiwan.

\section{Taiwan Developmental state Neo-liberalism Geographical industrialization Regional development}

Hsu J.-Y. et Cheng L.-L. (2002) Le développement économique d'après-guerre au Taiwan vu sous un nouvel angle: le processus dynamique de l'industrialisation géographique, Reg. Studies 36, 897-908. Au Taiwan, le développement économique d'après-guerre a été mirobolant, d'où des explications divergentes de la part des étudiants du développement économique. Alors que les néoclassicistes considèrent le miracle taiwanais comme un modèle type d'une économie de marché, les étatistes prône la politique gouvernementale. Cependant, ni les néoliberaux, ni les étatistes ne prennent au sérieux la notion de développement irrégulier. En ne tenant pas compte du processus d'industrialisation géographique, les deux discours ne peuvent dévoiler ni le rythme dynamique, ni, ce qui est plus important, la diversité ni la perspective du développement capitaliste. Cet article cherche à aborder la question en démêlant les trajectoires industrialo-régionales divergentes et l'ancrage socio-géographique dans le Taiwan d'après-guerre qui en résulte.

\section{Taiwan Etat de développement Néolibéralisme} Industrialisation géographique Aménagement du territoire
Hsu J.-Y. and Cheng L.-L. (2002) Rückkehr zur Wirtschaftsentwicklung in Nachkriegstaiwan: der dynamiche Prozeß geographischer Industrialisierung, Reg. Studies 36, 897-908. Taiwans Wirtschaftswachstum nach dem Kriege war spektakulär, und ist Gegenstand auseinandergehender, sogar gegensätzlicher Erklärungen von Wirtschaftswissenschaftlern gewesen. Neo-klassiker interpretieren Taiwans Wirtschaftswunder als ein Modell der freien Marktwirtschaft, während Befürworter des Staats in erster Linie die Regierungspolitik betonen. Jedoch nehmen weder Letztere noch die Neoliberalen das Phänomen der ungleichen Entwicklung sehr ernst. Da beide den Vorgang der geographischen Industrialisierung außer Acht lassen, sind sie nicht in der Lage, den dynamischen Rhythmus aufzuzeigen, noch, was wichtiger ist, Vielfalt und Möglichkeiten kapitalistischer Entwicklung. Dieser Aufsatz geht die Frage durch Entwirrung von einander abweichender, regionaler industrieller Flugbahnen an, und der sich daraus ergebenden geographischen und gesellschaftlichen Verankerung Nachkriegstaiwans.

Taiwan Entwicklungsland Neoliberalismus Geographische Industrialisierung

Regionale Entwicklung

\section{INTRODUCTION}

Taiwan's post-war economic growth has been spectacular and has attracted divergent, even contrasting, explanations from the students of economic development, particularly after the 1997 economic turmoil. While the issue of how to decode the East Asian Miracle had not been settled, the concern of how to interpret the 1997 turmoil has resulted in an existing divide among East Asian researchers. Those 
who believe the success of East Asia comes from the liberation of market forces conceive that the 1997 disaster was caused by the incompleteness of the market released by the governments (INTERNATIONAL MONeTARY FUND (IMF), 1998). In contrast, those who buy the idea of 'developmental state' tend to see the crisis as a conspiracy of the Wall Street-TreasuryIMF complex, which pushed East Asian governments to abandon their 'on-the-right-track' regulations of their own financial system, and believe governments have to bring back rules to weather the storm (W ADE, 1998).

These two perspectives of East Asian economic development appear to take extremely different stances: while the neo-classical theories advocate for the retreat of the state, the political economy approaches campaign for the empowerment of government. However, in reality they reach an unexpected agreement - both of them converge on the idea that national development is a spatially homogeneous process, and the regulation (or deregulation) of state policy will lead the nation to a new economic growth stage. Within this new stage, new leading sectors emerge and new employments increase.

These views are wrong or, at least, incomplete. A capitalistic economy never grows in a spatial vacuum, but in a process of geographical industrialization (StORPer and W AlKer, 1989). Capitalistic development reveals itself among divergent institutional embeddedness, structural coherence, geographical organizations and scalar connections, as HARVEY, 1982, argues. Space is treated as a resource that temporarily fixes the necessary contradiction of capital accumulation. ${ }^{1}$ From a geographical perspective, the industrialization process should not be taken as a temporal sequence of industrial substitution, but as a course of regional accumulation regimes that create locational factors, construct worlds of production and shape local geographical configurations.

Both statists and neo-liberalists make the same mistake in taking national development to be a universal phenomenon, and buy into the idea that the policy will have regular, either positive or negative, effects on the industrial system. In contrast, we differentiate the divergent developmental trajectories in different regions, even in the same country. By doing so, we are able to illustrate the rhythms of industrial change and related geographical organizations, and then provide a clearer understanding of the multiple modes of regional industrialization, and multiple modes of institutional regulation, in the presumed monolithic national development.

Taiwan's post-war economic growth was driven primarily by the expansion of manufacturing exports after 1960. It has become a commonly-accepted framework to divide its post-war economic development into three stages: the early push toward manufacturing exports in the 1960s; the import-substitution industrial- ization in the 1970s; and the industrial upgrading toward high-tech industries in the 1980s (GEREFFI, 1990). Variables like the Japanese colonial legacy (BARNETT and WhYTE, 1982), government policy (WADE, 1990), the international political economy (Cumings, 1987), the vulgar Confucianism (BERGER, 1986), labour suppression (DEy O, 1989), and networked production (SHIEH, 1992) have been selectively combined to offer explanations as to the country's economic success.

This paper does not aim to play as an impartial jury or to retell history by reshuffling the variables. Instead, this study starts off from the observation that those variables did not evenly shape the evolution of Taiwan's economy as if it was a homogeneous unit. Questioning the hidden assumption of a nation-state as the unit of analysis is not entirely an academic exercise. It is also a timely response to the pressing issues facing people in the turbulent world of the global economy, as the debate around the relationship between the regionalization and globalization process has intensified in the past decade (Омае, 1995; SсOTт, 1998).

The following discussion will focus particularly on the interplay of four elements at the regional level: industrial organization; state policy; market operation; and popular action by households, labour unions and professional networks. First, industrial organizations vary in accordance to the standing conventions, which legitimate the exploitation modes of resources and constraints (STORPER, 1997). Second, state policies carry divergent levels of capabilities to shape the context for the market mechanism to operate, while the constituted market further restructures the state autonomies in different localities (Evans, 1995). ${ }^{2}$ Third, the market mechanism is the social field where firms and institutions interact to allocate resources and the resulting well-being of each people and their surrounding regions (BLOCK, 1990). Finally, the actions taken by the popular sectors from the bottom will resist or legitimize the dominance of the above institutions, and shape the different industrial trajectories in different regions (HER OD, 1997). Investigating the difference of the interaction patterns in the divergent regions will illustrate the rich varieties of production worlds in Taiwan's post-war geographical industrialization process. In a sense, economic development is a historical question about socially-embedded industrial space and therefore also a challenge for turning limits into prosperity through our choices.

As is argued above, economic development is a historical result of the socially-embedded interaction between region and industry. Three industries are chosen as study subjects, because they represent the major stages and regions of Taiwan's post-war economic growth. They are the footwear industry, petrochemical industry and semiconductor industry. Their economic contributions (such as what percentage they have of manufacturing employment, gross value added and total 
Table 1. Economic performance of the three industries studied

\begin{tabular}{|c|c|c|c|c|c|}
\hline & 1976 & 1981 & 1986 & 1991 & 1996 \\
\hline \multicolumn{6}{|l|}{ Plastic shoes ${ }^{1}$} \\
\hline Annual total value of production (NT\$ billion) & $15 \cdot 1$ & $40 \cdot 4$ & $79 \cdot 2$ & $28 \cdot 4$ & $20 \cdot 8$ \\
\hline Value to total value of manufacturing (\%) & $1 \cdot 84$ & $1 \cdot 98$ & $2 \cdot 36$ & $0 \cdot 57$ & $0 \cdot 29$ \\
\hline Gross value added to total value of production (\%) & $23 \cdot 09$ & $25 \cdot 22$ & $31 \cdot 54$ & $34 \cdot 66$ & $30 \cdot 14$ \\
\hline Employment to total employment (\%) & $3 \cdot 59$ & $3 \cdot 96$ & $4 \cdot 42$ & $1 \cdot 47$ & $0 \cdot 47$ \\
\hline \multicolumn{6}{|l|}{ Petrochemical input ${ }^{1}$} \\
\hline Annual total value of production (NT\$ billion) & $40 \cdot 5$ & $124 \cdot 1$ & $228 \cdot 9$ & $303 \cdot 3$ & $464 \cdot 3$ \\
\hline Value to total value of manufacturing (\%) & $4 \cdot 95$ & $6 \cdot 08$ & $6 \cdot 82$ & $6 \cdot 13$ & $6 \cdot 41$ \\
\hline Gross value added to total value of production (\%) & $24 \cdot 83$ & $22 \cdot 24$ & $28 \cdot 70$ & $32 \cdot 20$ & $27 \cdot 97$ \\
\hline \multirow[t]{2}{*}{ Employment to total employment (\%) } & $2 \cdot 17$ & $2 \cdot 21$ & $2 \cdot 43$ & $2 \cdot 81$ & $3 \cdot 03$ \\
\hline & 1990 & 1996 & 1999 & & \\
\hline \multicolumn{6}{|l|}{ Semiconductor ${ }^{2}$} \\
\hline Annual total value of production (NT\$ billion) & 12 & $188 \cdot 2$ & $423 \cdot 5$ & & \\
\hline Number of firms & 82 & 113 & 237 & & \\
\hline Number of employment & 9,222 & 14,187 & 48,284 & & \\
\hline Employment to total employment (\%) & $0 \cdot 35$ & $1 \cdot 17$ & $2 \cdot 43$ & & \\
\hline
\end{tabular}

Sources: 1. Industrial and commercial censuses of Taiwan-Fukien district of the Republic of China, various years.

2. Yearbook of Semiconductor Industry of R OC, various years.

value of production) are shown in Table 1. Due to data availability, the input for plastic shoes and chemicals will stand for the categories of footwear and petrochemical inputs.

\section{REVISITING LOCAL ECONOMIES OF POST-WAR TAIWAN}

The footwear industry, once Taiwan's third largest exporting industry, grew on a massive scale during the export-oriented industrialization of the 1960s. Central Taiwan, especially the townships around its largest city, Taichung, was called the 'shoe nest', because it accommodated most of Taiwan's footwear manufacturers. The petrochemical industry was a representative of the import-substitution industrialization, which was ignited in the mid-1970s. Over $90 \%$ of petrochemical plants are concentrated around Kaohsiung's port in southern Taiwan. The semiconductor industry has become Taiwan's new rising star of industrial upgrading since the mid-1980s. All the semiconductor plants and most of their domestic manufacturing buyers are located in northern Taiwan.

These selections certainly do not mean that the industries have no presence outside their respective regions, nor do they imply that they monopolize the regional economies. The cases are selected, because of their historical affinities with development strategy and regional space. To disentangle the social content of the affinities, this research presents the following questions. What were the social conditions that spatially and historically gave birth to those representative industries of Taiwan's postwar economic development? Conversely, how did the development of those industries shape the social landscapes of regional Taiwan?
It must be admitted from the beginning that a detailed examination of the subject is impossible to accomplish in a short paper. The discussions that follow are inevitably sketchy and only give some broad strokes on the general features of these three industries in Taiwan. However, we hope that they are sufficient to at least reach an empirically-grounded conclusion that there were multiple paths of growth in a country as geographically small as Taiwan. More importantly, this research reveals that there was an inconstant industrialization process in capitalist development and regions served as the fix for the over-accumulation crisis. In a sense, geographical configurations of capitalist development were key to decoding the post-war economic miracle in Taiwan.

\section{THE FOOTWEAR INDUSTRY IN CENTRAL TAIWAN}

Taiwan was the world's largest footwear exporter between 1972 and 1988. The industry, especially its export sector, is concentrated in central Taiwan. The Taichung area, encompassing over $80 \%$ of footwear firms, is the ultimate powerhouse of the footwear industry - the 'shoe nest', as people in the industry have called it. The centre that has enjoyed the commanding height in this area is unarguably Taichung City, where most of the buyers are located.

The spatial distribution of footwear firms reveals the industry's historical origin. In the delta area of the Dachia River, located about 16 miles north of Taichung City, rushes flourished along the riverbank. Straw-hat production, which was based on women's household labour, developed in adjacent villages as a by-product of agriculture in the early eighteenth century. During 


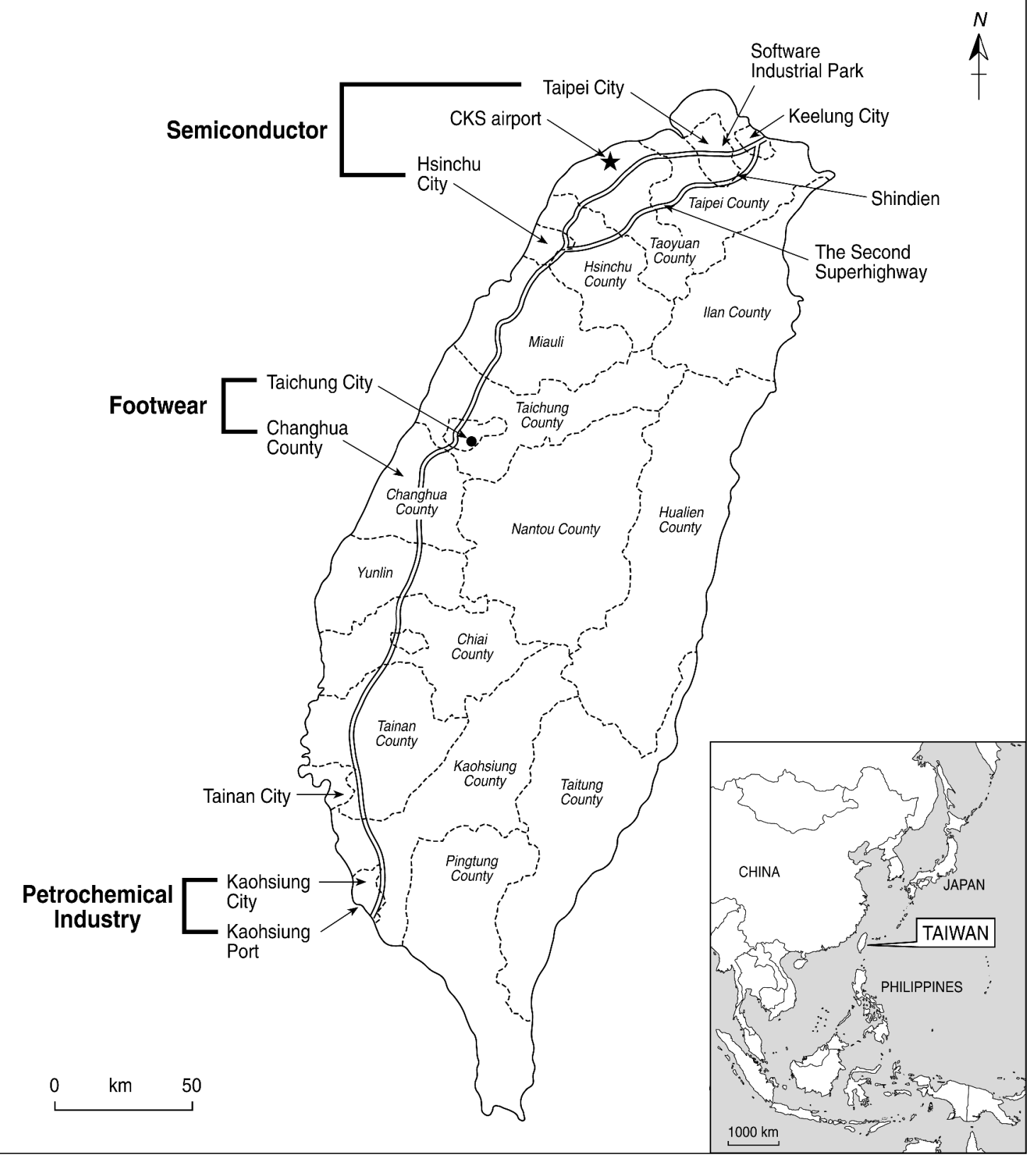

Fig. 1. Taiwan and the three regional industries

Japanese colonialism, straw-hat production reached its historic high in 1934, mainly through exporting to Japan (HsieH, 1964, pp. 335-36). After the devastation of World War Two, the straw-hat weaving industry emerged again, relying on the same female household labour. In the early 1960s, some businessmen started to experiment by exporting slippers made with strawweave uppers and plastic soles. This marked the beginning of the footwear export industry in Taiwan.

In 1967 there were about 30 footwear companies registered in Taiwan. They were concentrated in the area between Dachia and Chingshui, two towns located on either side of the Dachia River. Significant production and marketing networks developed among the early entrepreneurs, who shared market opportunities and technological know-how through informal networks (TAIWANESE FOOTWEAR MANUfaCTURERS' ASSOCIATION (TFMA), 1989). The president of a footwear factory reflects upon what was happening during the early days of his business:

At that time, Taiwan had just begun to push exports. People were amazed by how making shoes could earn them a little fortune. They were groping for manufacturing exports in a learning-by-doing fashion (bian$z u o-b i a n-x u e)$. Market information was passed around friends and relatives. For example, a glue maker would tell his relatives about opportunities for shoe-making which he got from his customers. A shoe maker would 
tell his best friend to set up a carton factory, you know, making money together (you-qian-da-jia-zhuan). Things like that were very normal at the time and people were extremely hard-working then. (Citation from CHENG, 1996).

Another one described the scene from a different perspective:

I was then working for the CICT (i.e. the footwear section of Mitsubishi) as an inspector. It was really interesting to see how people made shoes at that time. They made shoes inside the duck huts along a stream, beside a hog house, or in the backyard of a farmhouse. One time, the high-frequency molding of plastic shoes shut down the electric supply of an entire village for a while, and some even interfered with the operation of Taichung's military airport where US air forces were stationed. Military officers were surprised that the source of interruption came from the hog houses. As an inspector, I had seen all these. We, the inspectors of trading companies, were the unsung heroes of Taiwan['s] footwear industry. We moved around like bees spreading pollens among separated manufacturers so that innovations in manufacturing spread quickly. (ibid)

The industry grew rapidly in the late 1960s and then expanded into the hinterland of the Changhua plains the county just south of Taichung, in the 1970s. In the beginning, the majority of footwear exports were sold through Japanese trading companies. However, the intermediate role of these Japanese trading companies quickly declined. Taiwanese footwear producers eventually developed direct connections with American buyers by the mid-1960s. The footwear industry in Taiwan essentially developed through local capital and indigenous networks of the peasant economy.

Taiwan's footwear industry is mainly composed of numerous medium to small sized firms each specializing in a certain range of tasks and together constituting a highly responsive and competitive system. This is due to the fact that almost all the steps in footwear production (except final assembly) can be subcontracted. Firms working as subcontractors for the principal factories can be roughly classified into two broad categories: parts and processing firms. The former provide components or tools for footwear assembly, like outsoles, moulds, embroidery, patterns and cutting dies. The production of those components frequently requires investment in sophisticated machines or higher technical expertise, or specialized subcontracting.

The other category is comprised of processing firms that often did simple labour processing with less skill and machinery involved. Two major steps contracted out were upper stitching and lining cementing. In the 1970s, the contractors often passed additional work down to smaller workshops or households at the next tier. This is close to what HOLMES, 1986, calls 'capacity subcontracting' in the sense that it provided extra production capacity that principal firms mobilized forwhen market demand surged. The vertically- and horizontally-disintegrated production network lies at the core of the industry's flexible expansion.

The industry's first association, the Taiwanese Plastic Shoes Exporter's Association (TPSEA), was not established until 1968. Built upon its networks with the weaving and plastic industries, ${ }^{3}$ TPSEA proposed a 'minimum price agreement' in a national industrial conference with the Ministry of Economic Affairs (MOEA). The government responded to the proposal cautiously, agreeing to link export licensing with private pricing only if written agreements were reached among all association members. In addition, it agreed to block export permits only in a passive fashion by routinely following the approval stamps that exporters must first get from the association. It was the industry association that intentionally made use of government authority for a project they initiated, coordinated and actually enforced.

The aggressive image of the developmental state never existed in the footwear industry. It was a passive institutional supporter, not a far-sighted active participant. Both export volume and value doubled in 1970, the following year. From 1969 to 1976, up until the eve of the Orderly Marketing Agreement (OMA), the average annual volume increase was $64 \%$, despite the oil crises in the early 1970s.

Under mounting pressure from domestic footwear producers, the US government imposed quota restrictions on Taiwanese and Korean footwear exports between 1977 and 1980. Shocked by the quota, Taiwanese footwear producers still managed to upgrade and build even stronger ties with major footwear buyers. The number of registered footwear factories increased from just 75 firms in 1969 to 708 firms in 1981. As the industry grew over the years, a wellintegrated local industrial base, composed of supporting industries like machinery, synthetic leather, components, printing and mould making, was gradually formed, mainly around Taichung City. On the marketing side, following the steps of the early footwear importers, brand-name athletic shoe marketers came to Taiwan mostly in the late 1970s and early 1980s. By 1986, all the major athletic shoe brand names had wellestablished original-equipment manufacturing (OEM) supply lines in Taiwan. ${ }^{4}$ Central Taiwan had become an indispensable hub for the densely-connected networks of the world's footwear industry.

The abrupt appreciation of the Taiwanese currency against the US dollar directly hit the engine of footwear exports in 1986. The success story seemed to be drawing to an end. The number of registered firms reached its peak of about 1,245 in 1988 and then fell to 627 firms by 1994. In just a few years, Taiwanese footwear producers led the first wave of offshore investment in post-war Taiwan, a challenge that both Taiwanese firms and the state had never experienced before. Years after being a backbone of Taiwan's postwar economic growth, the footwear industry became 
the forerunner of Taiwan's international investment in the 1990s.

After the panic and frustration that had plagued Taiwanese footwear producers dissipated, a pattern of international operation began to emerge. The new structure is evidenced by several features: (1) nearly $85-90 \%$ of footwear exports from mainland China are now controlled by Taiwanese firms; (2) Chinese state enterprises were actually discouraged from footwear exporting by Taiwanese producers; (3) major footwear buyers, surprisingly even those volume retailers who are very sensitive to cost margins, remained in Taiwan; (4) Taiwan has become the world centre of footwear material and machinery supply; and (5) footwear sourcing transactions now operate in a triangle system where orders are received, materials are procured and models are developed in Taiwan, whole production is carried out in the coastal towns (e.g. new shoe nests, like Dongguang of Guandong Province) of southern China, and finished goods are shipped from Hong Kong. A new spatial strategy that globally connects sub-national regions into transnationally-defined regional networks is now in sight (HSING, 1998).

The footwear industry overall, as a representative of small to medium export-oriented firms in Taiwan, reached its peak in the early 1970s and was concentrated in Taiwan's Central Region of mainly rural areas. In the 'golden age' of the 1960s, Taiwan's labour-intensive industries took off, and achieved full employment to absorb a residential population of more than 1 million in the countryside, and alleviated the 'rural problem' caused by the agriculture crisis (BUCK, 2000). Such a developmental strategy met its limits while labour wages rose, while at the same time, protectionism arose in the major outlet, the US. As a result, this forced the state to intervene and adopt a second import substitution strategy to upgrade the industrial structure. Nevertheless, as the footwear case demonstrated, it was hard to argue that the state played a leading role in the process of rural industrialization in Central Taiwan.

\section{THE PETROCHEMICAL INDUSTRY IN SOUTHERN TAIWAN}

In the 1970s, especially after the oil crises, a window opened up for Taiwan, as well as for other developing countries, to develop their own petrochemical industries. At the time, the area around Kaohsiung's port in southern Taiwan was the first priority. Kaohsiung had already turned into a manufacturing base for heavy industries by the Japanese colonial government after the military invasion of South East Asia during World War Two. The colonization legacy allowed Kaohsiung to take advantage of the locational window of opportunity to become a major petrochemical area. In 1968, the first naphtha cracker plant was constructed in the Kaohsiung port area.

The plant was created within the policy situation that the state, without support from local private capital, pushed for the petrochemical industry to lead Taiwan's economic structure upgrading from light industry, such as plastic shoes, to heavy industry. As CHU, 1997, argues, the state played a critical role in fostering the petrochemical industry, and governed the market mechanism to reduce the amount of uncertainty in transactions. The sheer reality of creating an industry through cross-sector coordination of investments triggered an imitation effect on the industry's later development. Private capital became less hesitant in joining projects of a much larger scale. The direct costs in constructing large networks of pipelines and the indirect costs of the potential hazard in transporting petrochemical materials over long distances were factors crucial to the geographical agglomeration of factories in adjacent sectors of the petrochemical processing chain. A second cracker plant then joined the first one in 1971.

The two oil crises in the early 1970s shocked Taiwan into suddenly realizing that its economic growth was based on a fragile dependence on oil imports. The rising costs of oil worsened the problem of its underutilization. In 1976, the 'Ten Great Constructions', which were generally regarded as the beginning of import-substitution industrialization, were launched in order to strengthen Taiwan's infrastructure and to promote the country's upstream supply of basic raw materials. The plan for constructing the third naphtha refinery and its downstream industrial complex for the first time marked the petrochemical industry as a target for industrial policy. Its scale was massive, with estimated capital investment at close to NT\$ 4 billion. The state's capital was still the major investor and private and semi-private (i.e. KMT party) capital, which was encouraged by both the success of the first refinery and the expansion of the downstream export sector, stood at the tier of intermediate input production.

An institutional framework for governing the industry's development was established under the auspices of the KMT government. First, the estimated outputs of the third naphtha cracker plant were pre-allocated to the prospective intermediate input producers through extensive coordination to ensure sufficient demand and supply. Second, foreign competitors were discouraged from entering the domestic market by high tariffs (300\% for some items). Third, international sourcing of petrochemical materials at the firm level was subject to regulation that ordained domestic supply if foreign prices were similar. Fourth, price fixings were conducted through long-term supply contracts between sectors of the petrochemical chain in the name of cushioning international market fluctuation.

The uncertainty that these institutional arrangements had to cope with was specific to the industry's technoproduction basis. The automated process of continuous production on a massive scale had a fundamental influence on the petrochemical industry. Demand needed to 
be assured and to be stable for the industry's continuous expansion, particularly export growth. The abovementioned institutional features support the labourcapital compromise, mass consumption and welfare expenditure, which are fundamentally absent in other export-led sectors such as the footwear industry. However, as the export-oriented economy recovered from the oil crises slower than expected, the consequential scale of the third naphtha cracker plant shrunk by nearly half. The original plan was eventually divided into two stages with the fourth naphtha cracker plant in the planning stages to make up the difference. The fourth naphtha cracker plant was not finished until 1983 (Hsu, 1995).

After the mid-1980s, Taiwan's development of its petrochemical industry faced a new structural conflict between a freer market with unleashed private capital and an awakened society fuelled by political democratization. Under authoritarianism, the high polluting petrochemical industry had been developing in southern Taiwan without social resistance, which was geographically distant from the political centre of Taipei. Years of air and water pollution had caused serious human suffering to the people living in Kaohsiung City, not to mention those residents who lived close to the petrochemical industrial zones. Facing waves of labour and environmental protests in the 1980s, the plan for the fifth naphtha refinery was originally passed in 1986, but could not be constructed until 1994 (ibid).

Unlike the decentralized production networks in central Taiwan, which absorbed social conflicts by household self-exploitation, labour in the formal sector of the petrochemical industry was highly unionized and had greater labour consciousness and higher leverage to bargain with capital. The labour movements and environmental movements in the southern region of the petrochemical economy were destined to play the spearheads of social struggle against the social costs of Taiwan's miracle economy (HSU and HSIA, 1997).

The petrochemical industry demonstrated an ideal type of late industrialization, as AMSDEN, 1989, proposed. It was characterized by state leadership, learning advantage and conglomerate domination, and was governed by a labour-capital-state alliance, industrial complex and mass consumption. Industrial policies made by the state incubated the new industry, and state protection allowed the infant industry to grow and prosper. However, it encountered two key obstacles to expansion in the 1980s. Firstly, the awakening civil society resisted letting the environmentally-unfriendly industry extend its borders, leading to massive social unrest (HSU, 1995). Worst of all, cheap labour in other late industrializing countries lured the downstream industries (e.g. plastic processing and textiles) to leave and, as a result, the petrochemical firms were forced to follow suit. The state, being threatened by this hollowing-out crisis, pro-actively helped the petrochemical industry to find new host communities, particularly underdeveloped coastal areas. This has raised more confrontations between the states (both central and local levels) and environmental groups.

\section{THE SEMICONDUCTOR INDUSTRY IN NORTHERN TAIWAN}

Taiwan's integrated circuits (IC) industry consists overwhelmingly of specialized small to medium sized enterprises. Unlike huge vertically integrated conglomerates, IC firms in Taiwan operate around a finely detailed division of labour. By 1999, Taiwan hosted more than 230 IC firms, including 100 design houses, 5 in mask making, 21 fabrication firms, 42 in packaging and 33 in testing. Almost all of the important firms, including the top 10 design houses, and all of the fabrication and mask making firms, are located in the Hsinchu-Taipei Corridor, a region 60 miles wide. The largest one is the Taiwan Semiconductor Manufacturing Corporation (TSMC) whose initial funding, partly from government initiative, was $\$ 145$ million. Its sales revenues reached $\$ 1 \cdot 6$ billion in 1998 and $\$ 2 \cdot 4$ billion in 1999. By 2000, TSMC employed 14,000 people (including its overseas operation). It is a representative case of a developing country closing its gap with developed countries in a high-tech industry. The foundry strategy of Taiwanese semiconductor plants was an innovation that helped shape the competition in the global information industry. More than $85 \%$ of Taiwan's semiconductor firms are concentrated in the Hsinchu Science-based Industrial Park (HSIP) in northern Taiwan. The HSIP, and the corridor spreading from Taipei to Hsinchu, has become a successful regional model of learning in the developing world (Hsu, 1997; MATHEWs, 1997).

Hsinchu County is a small basin located in northern Taiwan. The rudimentary basis of the lighting industry, together with the petrochemical supply of natural gas, created the light bulb industry as a major export industry in Hsinchu before the birth of the information industry. The cheap power supply of natural gas gave rise to the glass industry, which then evolved into the light bulb industry, with Christmas string lights as the major product. The amount of light bulb factories in Hsinchu grew from only three in 1964 to over 500 in 1980. The Hsinchu area manufactured over $80 \%$ of total light bulb exports from Taiwan and helped the country reach the top in world light bulb output in 1980. At that time, the HSIP opened up with strong bureaucratic support on the edge of Hsinchu City. A brand-new chapter in local industrial history unfolded.

Retrospectively, the HSIP and its hosted hightechnology industries could not have been conceived without top-down state intervention in strategic promotion. It represented dramatic industrial leapfrogging in Hsinchu as a result of planning. Under the advice of a group of Chinese American engineers, the government established the Electronic Research Service Organization (ERSO) to transfer IC design and fabrication tech- 
Table 2. Public R\&D projects for IC industry

\begin{tabular}{|c|c|c|c|c|}
\hline Time-frame & EIDP-I: 1976-79 & EIDP-II: 1979-83 & VLSI project: $1983-88$ & ULSI project: $1990-94$ \\
\hline Expenditure (NT\$mn) & 489 & 796 & 2,921 & 5,500 \\
\hline Objectives & $\begin{array}{l}\text { - IC design and } \\
\text { manufacturing } \\
\text { technology acquisition } \\
\text { - establish pilot operation }\end{array}$ & $\begin{array}{l}\text { - improve pilot CMOS } \\
\text { facility } \\
\text { - acquire mask technology }\end{array}$ & $\begin{array}{l}\text { - establish VLSI process } \\
\text { technology } \\
\text { - acquire CAD for VLSI } \\
\text { ICs }\end{array}$ & $\begin{array}{l}\text { - acquire submicron } \\
\text { process technology } \\
\text { - establish ULSI pilot } \\
\text { plant }\end{array}$ \\
\hline Major features & $\begin{array}{l}\text { - } \text { pilot plant } \\
\text { - technology acquisition } \\
\text { and transfer } \\
\text { - personnel training }\end{array}$ & $\begin{array}{l}\text { - pilot plant improved } \\
\text { - LSI chips } \\
\text { - mask shop }\end{array}$ & $\begin{array}{l}\text { - VLSI chips } \\
\text { - VLSI pilot plant }\end{array}$ & $\begin{array}{l}\text { - ULSI chips } \\
\text { - ULSI pilot plant }\end{array}$ \\
\hline Technological capability & 7.0-micron CMOS & 3.5-micron CMOS & 1.0-micron CMOS & 0.5-micron CMOS \\
\hline Spin-offs & & UMC, Syntek, Holtek & TSMC, TMC, Winbond & VISC \\
\hline
\end{tabular}

Source: Adapted from LIU, 1993, p. 303.

nologies from foreign companies. After mastering the borrowed technologies, ERSO consequently spun off two new local IC firms, United Microelectronics Corporation (UMC) and Taiwan Semiconductor Manufacturing Corporation (TSMC). Aside from these major achievements, ERSO also set up an IC design centre, and allowed its engineers to start up their own companies. The government also established an industrial park to host these new firms, and provided financial and tax incentives to lure the risk investments. Through a series of projects, the state successfully assisted the local IC industry in becoming established (see Table 2).

In 1980 United Microelectronics Corporation (UMC), the first wafer fabrication factory in Taiwan, was established at the Hsinchu Science-based Industrial Park, with wholesale assistance in technology, personnel and equipment transference from the ERSO team. Under pressure from the government, private capital reluctantly agreed to invest under the condition that ERSO controlled 55\% of equity shares (HsU, 1997). Similar to the situation in the petrochemical industry, the government was leading the market (W ADE, 1990). The strategy of UMC was to specialize in the fabrication and testing stages, cooperate with other firms in the other stages (for example, packaging) and focus on the niche market of ASIC (application specific integrated circuit), which allowed it greater flexibility. ${ }^{5}$ The company was an instant success, reaching the break-even point in only two years.

In 1983, climbing a steeper learning curve, ERSO forged a joint research agreement with Vitelic, a very large scale IC (VLSI) design house in Silicon Valley founded by an overseas Chinese person, to develop advanced CMOS dynamic, random access memory (DRAM) technology. The project was initially successful with 256K DR AM. However, limited by Taiwan's capability to mass produce VLSI, its designs and those of smaller design houses in Taiwan were taken to Japanese or Korean IC factories for fabrication or sold to them. In 1986, TSMC (Taiwan Semiconductor Manufacturing Corporation), another spin-off of ERSO, began to produce VLSI on a commercial scale. Morris Chang, the former head of ITRI and now president of TSMC, designed a unique strategy for making TSMC the world's first pure fabrication factory with a high yield rate, good defect control and responsiveness to customer demand. ${ }^{6}$ The local design houses, no longer worried about fabrication capability, consequently flourished and their sales revenue increased from NT\$32 million in 1987 to NT\$236 million in 1990 . $^{7}$

The semiconductor industry in Taiwan entered a new 'phase of returnee establishments' (HsU, 1997) in the 1990s. Taiwan's PC industry reached a top position in the early 1990s, clearly surpassing Korea and Japan. The time lag between the introduction of new central processing units (CPUs) by Intel and the commercialization of the personal computer (PC) in Taiwan shortened from three years in 1982 (80286DX), to six months in 1989 (80486), to under one month by the time of Pentium II's introduction.

The vertically-disintegrated networks, composed of specialized firms manufacturing various peripherals and add-on cards, created a potential market for the semiconductor industry. More than 15 new wafer plants were constructed in the HSIP during the 1990s. Some of them were new investments undertaken by capital from other industries, who missed out on earlier opportunities (e.g. Formosa Plastics), some were an expansion by UMC and TSMC, and others represented backward integration of PC makers (e.g. Acer). The spin-offs of ERSO were no longer the only source of technological transfer and knowledge commercialization. Returnee start-ups, relying on the embodied knowledge of the founding teams and joint ventures with foreign hightech companies became increasingly important.

Although government intervention was the single most important factor in the early phase, the regional agglomeration of firms in the Hsinchu-Taipei corridor and the social networking that facilitates learning and innovation are gaining independent influence. As HSU, 1997, demonstrates, the geographical agglomeration of high technology firms in the region comes not from the static cost sharing, but from the dynamic interactive 
learning advantage in the technical community. In the learning region, the neighbouring institutions such as the two noted engineering universities (Tsinghua University and Chiaotung University) and ER SO provide not only high-quality human resources, but more importantly, the information and learning networks of friends and colleagues. These networks, added to the frequent turnover of personnel and returnee connections, became far more dynamic and complex in the industrial world of HSIP.

The semiconductor industry in Hsinchu is both locally chained (the Hsinchu-Taipei corridor, see HsU, 1997) and globally connected (Hsinchu-Silicon Valley connection, see SAXENIAN and HsU, 1999). Compared with the traditional networks of friends and relatives in the footwear industry, the social networks in the information industry are based more on the achieved networks that originate from the formal institutions of college education, workplace experience, business dealings and industrial associations (HSU and SAXENIAN, 2000). The networks are so dynamic and far reaching that they are able to create a local advantage while preventing the rigidity and inertia that tend to associate with local cohesion, but are detrimental to a knowledge-intensive industry.

\section{CONCLUSIONS AND IMPLICATIONS}

Although Taiwan is a country with relatively little land area, it has at least three distinctive regional economies with their own unique trajectories and crucial conjunctures of industrial development. This research argues that industries, institutions and regions are the three forces that together shape economic development in a path-dependent fashion. Industries refer to each specific world of products with their own unique market and technological sources of uncertainty. While the footwear industry is characterized by a highly competitive export market and massive labour utilization, the petrochemical industry demonstrates an extremely oligopolistic domestic market and huge capital investment.

Institution refers to the various social forces that provide the means for economic coordination and governance. The industrial association in the footwear industry settles the quota allocation issue to construct a collective order for the numerous small firms, and the state-capital-labour alliance contributes to the functioning of the industrial system among the less than 30 petrochemical firms. As for the semiconductor industry, the governing institutions have intermediate characteristics - state leadership at the initial stage and technical community for further development. Finally, regions refer to the social mechanisms underlying the spatial concentration of industrial networks. They provide the temporal-spatial context for social embeddedness and the locale for economic contests. Table 3 summarizes the content in a concise format.

The existing explanations on Taiwan's economic development, as well as other East Asian miracles, often ignore regional and industrial differences and have their own preferred industries and explanatory variables. Theories are more valid when they deal with the industry and the stage of development that have the strongest affinity with their core variables. While statists base their arguments about the aggressive roles played by the late-industrializing states in case studies of petrochemical (AMSDEN, 1985) and semiconductor sectors (WADE, 1990; MATHEWs, 1997), neo-liberalists refute them by using data about small and medium sized enterprises in labour-intensive sectors to illustrate the flexibility advantage and export orientation, which is assumed to match the free-market paradigm and is void of government's spoiling subsidies and disturbing regulation. They fall short when stepping out of their territory, and can only convince their own true believers. Given the complexity of regional economies, as shown above, we need a set of concepts to picture the overall structures of regional industries.

This research fleshes out the key roles played by regions in national economic and social development. Nowadays, people have increasingly realized that "development' can no longer be measured quantitatively by a monetary scale like GNP per capita (SEN and Muellbauer, 1987; Block, 1990). The achievement and pain of economic development can only be truly evaluated by closely examining the locales where people struggle to make a decent and sustainable living. The economic development of Taiwan is not a single story. The footwear industry of central Taiwan, the petrochemical industry of southern Taiwan, and the semiconductor industry in northern Taiwan represent three possibilities for economic development and three social landscapes of human consequences. The regional economies are where the stories of development begin, turn and twist.

This research also resonates the arguments made by institutional geographies, such as that which STORPER, 1997, proposed. It is suggested that the different industrial trajectories taken by different regions and their consequent institutionalized proactive capacities will result in the uneven restructuring process as new economic opportunities or threats emerge. For example, it is expected that Taiwan's participation in the World Trade Organization by the end of 2001 (estimated) will hit the Central Region seriously by devastating the outflow of labour-intensive industries, but benefit the Northern Region by enhancing trade for high technology products (MOEA, 2000). At the same time, the emerging crossborder connections between the regions in different national contexts, such as the Silicon Valley-Hsinchu connection, will build up the territorial units for a globalization architecture. Different governing mechanisms in divergent regions will allow different forms of participation in the global economy, and further transform globalization itself. The case of the different institutionalized spaces in 
Table 3. The formation of the three regional industries in Taiwan

Technological charact
Labour process
Market characteristics

Marketing positioning

Bottleneck for early entry

Major competitor

Growth period

National development strategy in background

Space of industrial development

\section{Regional centre}

Dynamism of geographical

concentration

Historical legacy

Embeddedness in the local society High

Role of the state

Policy tools

Trade union

Industrial crisis

Destinations for

internationalization

Explanatory variables

Quota management and trade negotiation

\section{Underdeveloped}

Rising labour costs, new competitors, protectionism since the 1980 s

Southern China, Vietnam, and Indonesia (for cheap labour)

Managing logic of peasant economy, networked form of labour control

Petrochemical industry

Capital (/technology) intensive

Large batch, continuous process

Standardized materials, long product cycle, stable market demand crucial

Supplying downstream domestic processors

Large scale of both stable demand and capital inputs South Korea

1970s-1990s

Import-substituted industrialization

Industrial zones in Kaohsiung

County of southern Taiwan

\section{Kaohsiung City}

Transportation costs mainly

(close to the port for crude oil import and the safe

transportation of processed oil)

Japanese colonialism turned the

Kaohsiung port into a heavy

industry centre for supporting

southward expansion into

southeast Asia, early

petrochemical plants were

constructed

Low

Aggressive player

Market protection and direct investments

Coordinating market orders and stabilizing prices

Highly developed

Environmental protest, offshore

investment of downstream

industries since 1980s

Fu-Jian (China), Thailand,

Malaysia (close to market or materials)

Industrial policy, market intervention, development alliance
Semiconductor industry

Knowledge (/capital) intensive Sophisticated, but dividable automation

Big waves between DRAM transition; investment timing crucial; ASIC chip emphasizing design capability

Contract manufacturing to specialized foreign and domestic buyers

Technological and capital barrier

South Korea, Japan

1980s-1990s

Industrial upgrading towards

high-tech industries

Information corridor between

Shindien and Hsinchu in

northern Taiwan

Taipei City

Learning costs mainly

(knowledge and information

diffusion and acquisition)

Political centre since Japanese colonialism, post-war strengthening of the culturalpolitical centre, major universities and research centres, global linkages through metropolitan Taipei

Medium

Ardent 'gardener'

Establish research institutes and

scientific park (speeding entrepreneurial spin-off, innovation diffusion, and commercialization)

Promoting strategic cooperation and participating in international standard setting

Professional community

Sudden global stagnation in the late 1990s; economic recovery deterred; design capability still to be improved

China, Western Europe, and US (human resource, knowledge and market access)

Organizational alliance, technological diffusion, professionalism

Source: CHENG, 1999.

Taiwan's three regions bolsters the argument that a regional political economy (accepting as a basic premise the intersection between a globalizing world economy and uneven development) will be critical to the understanding of the varieties of capitalist systems (A GNEW,
2000). Without taking the divergent patterns of regional industrialization into account, the theoretical explanations and their induced practical suggestions will not be comprehensive in knowledge creation and constructive in policy making. 
Acknowledgements - Both authors have contributed equally in the discussion, analysis and writing process for the paper. Thanks to two anonymous referees for valuable comments. Finally, Jinn-yuh Hsu expresses gratitude for the financial support from Taiwan's National Science Council (Grant No. NSC 89-2415-H-003-007-). The usual disclaimer applies.

\section{NOTES}

1. Here, we agree to use the term 'spatial fix' originated by Harvey, rather than the term 'spatio-temporal fix' which was proposed by JESSOP, 2000, in a recently published paper. Jessop based his criticism on Harvey's ignorance of the time dimension in the capitalist regulation of accumulation regime. For Harvey, the temporal dimension of capital fixity and motion was incarnate in the discussion of the process of change and structural coherence between regions. Therefore, we still use 'spatial fix' which is familiar to critical geographers. Moreover, labour geographers such as HEROD, 1997, argue that we should pay more attention to labour's role in the making of spatial fix. It is true that labour as the active agent in the process of production could use space as the resource to fight against the capital accumulation strategy which might endanger the survival and prosperity of the worker community. However, one should not pretend that labour as a collectivity possesses the same capacity and stands on an equal footing with capital in shaping the economic landscape, since different collective logics exist between these two agents. Herod's argument should be treated as being complementary, rather than substitutive, with Harvey's.

2. From a historical materialist perspective, the state is not just an entity, but a process. In other words, we have to pay attention to the shifting formation of hegemonic class alliance as capitalist development evolves along the geographical industrialization process (HARVEY, 1982). States will take different moves to cover the capital interest under varying local circumstance. In the Marxist term, the state is not necessarily a capitalist agent with an ability for far-sighted decision making as the statists argued, but is in a dialectical process of interplay with divergent class groups. We thank Harvey for reminding us of this point at the International Critical Geography Group Conference, Taegu, Korea, August 9-13, 2000.

3. The executive director of the association held the same position at the Taiwanese Hat Exporter's Association (THEA). The counselling committee of TPSEA was composed of the chairman of THEA and owners of the five major plastic companies (TFMA, 1989). They showed the networking efforts of the industry in its infancy to assure the stability of the resource environment.

4. The first brand buyer to place orders in Taiwan was Adidas in early 1971, bringing in the most advanced production technology at the time.

5. In a sense, it is quite similar to the strategy that the firms of more traditional industries in Taiwan have been following.

6. The similarity of the so-called 'specialized subcontracting' to IEM, which has been the model for manufacturing exports in Taiwan, hints of a profound industrial convention in Taiwan.

7. Following the greenhouse strategy, a spin-off of a new mask production company based on advanced technology was built in 1988. Over 100 engineers and staff from the mask division at ERSO were transferred to the new company, Taiwan Mask Corporation (TMC). The company has enjoyed revenue growth of 15-20\%, from around NT\$300 million in 1989 to around NT\$500 million in 1994.

\section{REFERENCES}

A GNew J. (2000) From the political economy of regions to regional political economy, Prog. Hum. Geogr. 24(1), 101-10.

Amsden A. (1985) The state and Taiwan's economic development, in Evans P., Rueschemeyer D. and Skocpol T. (Eds) Bringing the State Back In. Cambridge University Press, New York.

Amsden A. (1989) Asia's Next Giant: South Korea and Late Industrialization. Oxford University Press, New York.

Barnett R. E. and Whyte M. K. (1982) Dependency theory and Taiwan: analysis of deviant case, Am. J. Sociol. 87, 1,064-89. Berger P. L. (1986) The Capitalist Revolution: Fifty Propositions about Prosperity, Equality, and Liberty. Basic Books, New York.

Block F. (1990) Postindustrial Possibilities: A Critique of Economic Discourse. University of California Press, Berkeley, CA.

BuCK D. (2000) Growth, disintegration, and decentralization: the construction of Taiwan's industrial networks, Environ. Plann. A 32(2), 245-62.

Cheng L.-L. (1996) Embedded competitiveness: Taiwan's shifting role in the international footwear sourcing networks. Ph.D. thesis, Department of Sociology, Duke University, Durham, NC.

Cheng L.-L. (1999) One country, three systems: local economies in Taiwan's post-war economic development, in The Miracles and Crises of Asian Economies: A Historical Perspective, pp. 99-130. The Academy of Korean Studies, Seoul.

Chu W.-W. (1997) Demonstration effects and industrial policy: the birth of Taiwan's petrochemical industry, Taiwan: A Radical Quarterly in Social Studies 27, 97-138 (in Chinese).

Cumings B. (1987) The origins and development of the Northeast Asian political economy: industrial sectors, product cycles, and political consequences, in DEyo F. C. (Ed) The Political Economy of the New Asian Industrialism. Cornell University Press, Ithaca, NY.

Deyo F. (1989) Beneath the Miracle. University of California Press, Berkeley, CA.

Gereffi G. (1990) Paths of industrialization: an overview, in Gereffi G. and Wyman D. L. (Eds) Manufacturing Miracles, pp. 3-31. Princeton University Press, Princeton, NJ.

Harvey D. (1982) The Limits to Capital. The University of Chicago Press, Chicago. 
Her OD A. (1997) From a geography of labor to a labor geography: labor's spatial fix and the geography of capitalism, Antipode 29(1), 1-31.

Holmes J. (1986) The organization and locational structure of production subcontracting, pp. 80-106 in ScOTT A. and Storper M. (Eds) Production, Work, Territory: The Geographical Anatomy of Industrial Capitalism. Allen \& Unwin, Boston.

Hsien C.-M. (1964) Taiwan - Illa Formosa: A Geography in Perspective, Butterworth, London.

Hsing Y.-T. (1998) Making Capitalism in China: The Taiwan Connection. Oxford University Press, New York.

Hsu J.-Y. (1995) The struggle over local space: a case study of the environmental movement in Taiwan, Capitalism, Nature, Socialism 6(1), 113-24.

HsU J.-Y. (1997) A late-industrial district? Learning network in the Hsinchu Science-based Industrial Park, Taiwan, Ph.D. thesis, Department of Geography, University of California, Berkeley, CA.

HSU J.-Y. and Hsia C.-J. (1997) Petrochemical industry and localities in Taiwan: a comparative study, Taiwan: A Radical Quarterly in Social Studies 26, 129-166 (in Chinese).

HSU J.-Y. and SAXENiAn A. (2000) The limits of Guanxi capitalism: transnational collaboration between Taiwan and the US, Environ. Plann. A 32(11), 1,991-2,005.

International Monetary Fund (1998) IMF Survey 27(6), March.

Jessop B. (2000) The crisis of the national spatio-temporal fix and the tendential ecological dominance of globalizing capitalism, Int. J. Urban \& Reg. Res. 24(2), 323-60.

LiU C.-Y. (1993) Government's role in developing a high-tech industry: the case of Taiwan's semiconductor industry, Technovation 13(5), 299-309.

Mathews J. (1997) A Silicon Valley of the East: creating Taiwan's semiconductor industry, Calif. Mgt. Rev. 39(4), 26-54.

Ministry of Economic Affairs (MOEA) (2000) Taiwan's Industrial Policy Toward the 21st Century. MOEA, Taipei.

Omae K. I. (1995) The End of the Nation State: The Rise of Regional Economies. Free Press, New York.

SAXENian A. and Hsu J.-Y. (1999) Transnational entrepreneurs and regional industrialization: the Silicon Valley-Hsinchu connection, presented at the annual conference of the Association of Collegiate Schools of Planning, Chicago, October.

Scott A. (1998) Regions and the World Economy: The Coming Shape of Global Production, Competition and Political Order. Oxford University Press, Oxford.

Sen A. and Muellbauer J. (1987) The Standard of Living. Cambridge University Press, Cambridge.

Shien G. S. (1992) 'Boss' Island: The Subcontracting Network and Micro-Entrepreneurship in Taiwan's Development. Peter Lang, New York.

Storper M. (1997) The Regional World: Territorial Development in a Global Economy. Guilford Press, New York.

Storper M. and W alker R. (1989) The Capitalist Imperative: Territory, Technology and Industrial Growth. Blackwell, New York.

Taiwanese Footwear Manufacturers' Association (TFMA) (1989) 30-Year History of Taiwan's Shoe Manufacturing Industry. TFMA, Taipei.

Taiwanese Footwear Manufacturers' Association (TFMA) (1995) Statistical Data. TFMA, Taipei.

W ADE R. (1990) Governing the Market: Economic Theory and the Role of Government in East Asian Industrialization. Princeton University Press, Princeton, NJ.

W ADE R. (1998) From 'miracle' to 'cronyism': explaining the great Asian slump, Camb. J. Econ. 22(6), 693-706. 